\title{
Study of mercury behavior and earthworm bioassays in three solid environment components from selected areas of Eastern Slovakia
}

\author{
Šestinová O.*, Hančulák J., Dolinská S., Findoráková L. and Špaldon T. \\ Institute of Geotechnics, Slovak Academy of Sciences, Watsonova 45, 04001 Košice, Slovak Republic \\ Received: 23/02/2018, Accepted: 06/05/2019, Available online: 10/05/2019 \\ *to whom all correspondence should be addressed: e-mail: sestinova@saske.sk
}

https://doi.org/10.30955/gnj.002641

\section{Abstract}

A 28-day bioassay with the earthworm (Dendrobaena veneta) was used to assessing the ecotoxic effect of mercury in study soils and sediments. This article deals with quality evaluation of the soils, sediments and plants (assimilation organs) from three localities, Rudňany, Krompachy, and water reservoir of Ružín, Eastern Slovakia (Europe) in consideration of their toxic effect on the environment. These areas are well - known for its mercury mining and metallurgical activities for several centuries. Within the frame of evaluation it was found that the concentrations of mercury exceeded some of the MPC (Max. Tolerable Risk) and IV (Serious Risk) values. The samples Rudňany tailing-SED (188.5mg/ $\mathrm{kg})$, Krompachy a-SED (69.4 mg/kg), and Krompachy b-SED (93.4 mg/kg) were the most polluted by mercury, which is evident according to it is the highest mortality on the earthworm (Dendrobaena veneta). The high mercury concentrations were obtained in the soils of the Rudnany-tailing-S $(82.5$ $\mathrm{mg} / \mathrm{kg})$, Rudňany-tailing, valley-S $(57.8 \mathrm{mg} / \mathrm{kg})$, and Krompachy $4 \mathrm{KO}-\mathrm{S}(20.6 \mathrm{mg} / \mathrm{kg})$. A significant positive correlation is found between highest concentrations of mercury Rudňany-tailing SED $\mathrm{Hg}=188.5 \mathrm{mg} / \mathrm{kg} \quad(\mathrm{r}=0.87$ ) with the highest mortality of Dendrobaena veneta after 28 days bioassay.

Keywords: Soil, sediment, plant, mercury, earthworm.

\section{Introduction}

Soil contamination can seriously and negatively impact soil life, especially persistent soil contaminants such as mercury. The presence of mercury and other contaminants hampers basic soil ecosystem processes such as organic matter degradation. Plant growth may also be hampered by the high contamination either directly, by the impact of mercury, or indirectly, by the changed soil and litter environment (Eijsackers, 2010). Mercury from the source of pollution is transported by soil, water in river and accumulated in sediments. The anthropogenic mercury input into the environment is more miscellaneous compared to the natural one.
The main sources are for example: mining dumps, ore transport, aerosols, agriculture, electronics, batteries, and waste facilities. Subsequently, mercury and mercury compounds enter into atmosphere, hydrosphere and pedosphere, where they change during it is cycles and the result of these processes is the increase of toxicity (Hinton and Veiga, 2009; Zhang et al., 2016). High ecological risk of mercury comes from its specific properties. Mining operations with the metallurgical processing of complex metals and copper ores left negative effects on the region Eastern Slovakia, Krompachy and water reservoir of Ružín. In the river basin Hornád and Hnilec, there are several old, abandoned, and flooded mining works as well as mining dumps resulting as mining, treatment and metallurgical processing of $\mathrm{Cu}, \mathrm{Fe}$, and $\mathrm{Hg}$ ores containing impurities of toxic elements. Siderite deposit of Rudňany belongs to risk localities (Šestinová et al., 2015). A better understanding of ecosystem functioning and bioavailability to buffer the negative impacts of mercury contamination could be obtain by more various screening methods. The majority of bioassays applied to contaminated sediments and soils are based on the toxic effects of sediment solutions or sediment itself on a living organism (e.g. animals, plant and bacterial bioassays). Because bioassays are a direct measure of functional responses, they should have more impact on the decision-making process than criteria based on the concentrations of chemicals alone (CzerniawskaKusza and Kusza, 2011; Das and Chakrapani, 2011). Earthworms are distributed widely in terrestrial ecosystem and are very active contributors to soil formation, giving shape to physico-chemical and biological properties of soil, thus enhancing soil fertility (Maity et al., 2018). Earthworms are known for their bioaccumulation capacity of organic or inorganic contaminants (De Vaufleury et al., 2013). Also, authors Nannoni et al. (2014), the bio-concentration of metal trace elements in earthworms at urban, peri-urban and garden levels in the City of Siena (Italy) has been measured. In study (Mariyadas et al., 2018) were examined silver nanomaterials cause toxicity to earthworm, with effects 
on survival, reproduction and enzyme activity. Some works has attempted to link bioaccumulation with the socalled "bioavailable" fraction in soils on this type of organism for trace elements (Coelho et al., 2018).

Also, morphological and histopathological analyses have been used to identify tissue damage caused by exposure to sewage sludge in terrestrial invertebrates (Eisenia fetida), in order to gain a better understanding of adverse effects caused by sewage sludge and to analyse its impact on the production of reactive oxygen species and lipid peroxidation in earthworms, were measured (Nogarol and Fontanetti, 2010; Christofoletti et al., 2012; Babić et al., 2016).

The research was aimed to mercury distribution and their toxic effects in the soils, sediments and plants ((spruce, pine, birch) using bioassays, tests of mortality of Dendrobaena veneta.

\section{Materials and methods}

\subsection{Soil, sediment and plant sampling}

The soil samples from two areas (Krompachy and Rudňany) and the sediment samples from three areas (water reservoirs Ružín No.I and Krompachy, and tailing Rudňany) were used for the analysis (Figure 1). The Rudňany deposit is situated in the northern part of the Spišsko-Gemerské Rudohorie Mountains (Spišská Nová Ves). The location of the water reservoir Ružín is situated in the Valley of Volvos' Mountains and Hornád basin. In the years 2014-2015 sediments from two sites at the water reservoir Ružín Nol. (Hornád and Hnilec River), and two sites at the water reservoir Krompachy $(a, b)$ were collected. In the year 2015, the four sampling sites (depth was $0.05-0.20 \mathrm{~m}$ ) were localised on area of the villages Krompachy: $1 \mathrm{KL}$ (Kluknava), $2 \mathrm{KL}$ (Kluknava), 3KR (Krompachy) and 4KO (Kolinovce). The highest concentrations of $\mathrm{Cu}, \mathrm{Pb}, \mathrm{Zn}$, As and $\mathrm{Hg}$ were detected on the sampling sites up to $3 \mathrm{~km}$ from the plant Kovohuty a.s., Krompachy, (Šestinová et al., 2015; Angelovičová et al., 2015). The plant Kovohuty a.s. represents one of the most important sources of emissions. Soil samples were sampled from the top soil horizon (upper $20 \mathrm{~cm}$ ) and sediments at a depth of $50 \mathrm{~cm}$. The samples were air dried at room temperature, and the mixed samples were thoroughly mechanically homogenized. Soil samples were fine sieved $(<2 \mathrm{~mm})$ and sediments $(<1 \mathrm{~mm})$ to minimize compositional heterogeneity before chemical analysis.

Presented sort of tree species (spruce, pine, birch) were selected from the reason of their most frequent occurrence in the monitored areas (outdoors) as well as for a possibility of the comparison of mercury content and its mobility in the soils, sediments and plant (assimilation organs). These tree samples (fresh leaves of birch; and spruce and pine needles) were collected in each of the autumn seasons of the years 2006-2015. For analysis of biota were used the mixed tree samples of $1 \mathrm{~kg}$ weight. The tree samples were washed by distillate water, and then dried for one week, at $25^{\circ} \mathrm{C}$, homogenized and was used on chemical analyses. The total content of mercury in the samples was analyzed by the trace mercury analyzer (DMA-80) without mineralization. All the analyzed samples were conducted in triplicate and the data were based on samples dry weight.

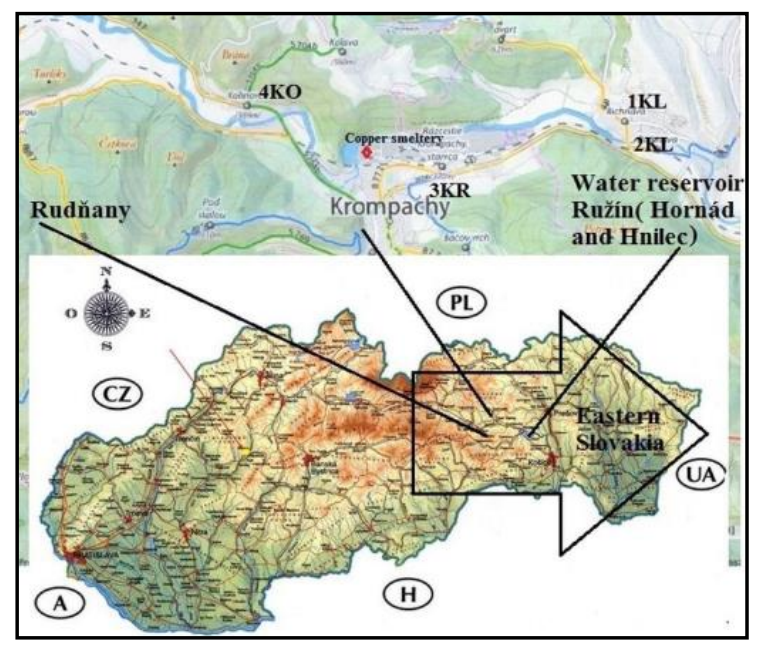

Figure 1. Studied areas

Granulometric analysis was performed on a set of soil and sediment samples. Firstly, the samples were wet sieved to separate the coarser particles $(>63 \mu \mathrm{m})$, then a decantation process was carried out (gravity settling in deionized water) to characterize the finer fraction. All sediment samples contained the sand, silt and clay fractions. The silt and clay fractions were determined as the percentage of the sediments passing through a sieve with an opening size of $63 \mu \mathrm{m}$. Soil types were by silty-clay texture. The used control soil contained: $85 \%$ quartz, $10 \%$ kaolin and $5 \%$ peat. The quality of the soil was established with reference to law (220/2004, No.2, Slovak Republic) from various areas to keep representativeness. The quality of the sediment was established with reference to methodical instructions of the Ministry of Environment of the Slovak Republic 549/1998-2 and by law 203/2009 for assessing risks from pollution of sediments streams and water reservoirs. The values obtained were compared with the test values (TV), the maximum permissible concentrations (MPC) and the intervention values (IV), which are listed in Table 2.

\subsection{Earthworm bioassay}

The experiments were carried out as described in the OECD Guidelines 317 for the testing of chemicals relating to environmental fate, tests of mortality. The reaction to the earthworm (Dendrobaena veneta) was used for chronic tests in the soils and sediments. Earthworms are often used as terrestrial model organisms for ecotoxicity testing, because of their importance for the structure and function of soil ecosystems (Eijsackers, 2010). The earthworms were purchased from a local supplier. Prior to the start of the experiment, the earthworms were allowed to acclimatize for one week in the experimental conditions. The adult worms were used in the tests. Three replicates were performed for each test (of the soil $100 \mathrm{~g}$ dry weight) with ten earthworms added to each boxes. Then distilled water was added for purpose to 
obtain $30 \%$ moisture of soil. After that, the boxes with soils (sediments) were kept for 28 at laboratory temperature. The earthworms were lyophilized (at temperature $-50^{\circ} \mathrm{C}$ and pressure $50 \mathrm{~Pa}$ ) and the concentrations of mercury after 28 days earthworms exposure were measured direct by trace mercury analyzer DMA-80. The results were evaluated as the percentage inhibition of mortality and compared to the control soil.

Table 1. Main physicochemical parameters and granulometric distribution in the soils and sediments

\begin{tabular}{|c|c|c|c|c|c|c|c|}
\hline \multirow[b]{2}{*}{ Area } & \multirow[b]{2}{*}{$\mathrm{pH} / \mathrm{H}_{2} \mathrm{O}$} & \multirow[b]{2}{*}{ Eh (mV) } & \multirow[b]{2}{*}{$\begin{array}{l}\text { Organic matter } \\
\text { d.w. (\%) }\end{array}$} & \multicolumn{4}{|c|}{ Grain size $(\mu \mathrm{m})$} \\
\hline & & & & $\begin{array}{c}>100 \\
(\%)\end{array}$ & $>63(\%)$ & $>40(\%)$ & $\begin{array}{l}<40 \\
(\%)\end{array}$ \\
\hline Hornád River SED & 7.2 & 148 & 12.8 & 1.4 & 3.3 & 20.4 & 77.9 \\
\hline Hnilec River SED & 7.5 & 288 & 10.5 & 2.1 & 5.2 & 24.6 & 68.1 \\
\hline Krompachy $1 \mathrm{KL}$ - PGV $S$ & 6.7 & 504 & 6.2 & 2.8 & 11.9 & 19.5 & 65.8 \\
\hline Krompachy $2 \mathrm{KL}$ - A $S$ & 6.5 & 582 & 5.6 & 3.7 & 11.5 & 18.7 & 66.1 \\
\hline Krompachy 3KR - PGV $S$ & 6.8 & 602 & 7.6 & 0.7 & 6.7 & 19.8 & 72.8 \\
\hline Krompachy 4KO - PGV $S$ & 7.6 & 582 & 7.3 & 4.5 & 6.5 & 18.2 & 70.8 \\
\hline Krompachy - a SED & 7.7 & 259 & 14.6 & 2.8 & 5.2 & 34.9 & 57.1 \\
\hline Krompachy - $b$ SED & 7.3 & 129 & 16.2 & 1.8 & 3.6 & 33.8 & 60.8 \\
\hline Rudňany-Markušovce $\boldsymbol{S}$ & 5.6 & 686 & 9.8 & 4.2 & 12.3 & 14.9 & 68.6 \\
\hline Rudňany - tailing $S$ & 4.9 & 673 & 5.4 & 3.1 & 7.2 & 15.8 & 73.9 \\
\hline Rudňany - tailing, valley $S$ & 5.7 & 651 & 8.7 & 2.9 & 10.5 & 17.1 & 69.5 \\
\hline Rudňany - tailing SED & 7.1 & 547 & 13.5 & 0.1 & 5.0 & 9.5 & 85.4 \\
\hline
\end{tabular}

S-Soils, SED-Sediments, PGV-permanent grass vegetation soils, A-agricultural soils, Organic matter dry weight (d.w.) - (according to STN EN 12879) organic proportion determination of dry matter losses during combustion

\section{Results and discussions}

3.1. The physicochemical parameters and mercury concentrations in different types of samples

The physicochemical properties of the sediment from the Hornád and Hnilec Rivers, the $\mathrm{pH}$ were in the range 7.2-7.5 indicate near-neutral, likely due to a higher content of carbonates in the bottom sediments (Table 1). The organic matter of studied sediments ranged from 10.5 to $16.2 \%$. Krompachy soils and sediments measurements indicated similar $\mathrm{pH}$, with values ranging from 6.5-7.7. The $\mathrm{pH}$ of the soils from the area Rudnany was in the range 7.1-7.7 and for the sediments was in the range 7.1-7.8. This $\mathrm{pH}$ indicates slightly alkaline samples because the acidity generated by decomposition of the sulfides is efficiently neutralized by the abundant carbonate minerals. The most frequent primary minerals are siderite, quartz, barite, and muscovite (Kučerová et al., 2014). The organic matter of soils ranged from 5.4 to $9.8 \%$. Total mercury concentrations, mercury concentration of the samples after bioassay and accumulated in Dendrobaena veneta earthworm tissues during a 28-day bioassay in soil and sediment are shown in Table 2. From the Table 2 it is evident that the most contaminated sediment is sediment Rudňany tailing-SED (188.5 mg/kg), Krompachy a-SED $(69.4 \mathrm{mg} / \mathrm{kg})$, and Krompachy b-SED (93.4 mg/kg). The high mercury concentrations were obtained in the soils of the Rudňany-tailing-S (82.5 $\mathrm{mg} / \mathrm{kg})$, Rudňany-tailing, valley-S $(57.8 \mathrm{mg} / \mathrm{kg})$, and Krompachy $4 \mathrm{KO}-\mathrm{S}(20.6 \mathrm{mg} / \mathrm{kg})$. Also it was found that earthworms decrease the mercury concentration after 28 days earthworms exposure mainly in the Rudnany tailing. In Table 3, there are the results of the mercury concentration in the plant samples (Rudňany). This metal is released into aquatic environments in response to changes in redox due to oxidation and subsequent degradation of organic substances and decomposition of sulfides by changing physicochemical conditions. According to the authors (Šestinova et al., 2015; Aydin et al., 2018), it was found that sequential extraction revealed high bioavailability of $\mathrm{Hg}$ in the sediments, which are primarily of anthropogenic origin and organic bound metals extracted in organicsulfide fraction. It is considered, that mercury is bound with stable humic substances. Also, when pollution due to metals enters the lake environment, it is incorporated into sediments with organic matter, sulfides, clay and iron/manganese (Fe/Mn) oxides. Study (Yin et al., 2016) showed also that different cultivation practices can largely change the distribution and speciation of $\mathrm{Hg}$ in agricultural soils. In the assimilation organs trees were measured very low values of mercury (0.031-0.270 $\mathrm{mg} / \mathrm{kg}$ ). Maximum of mercury concentration was detected in the birch leaves in the area Rudňany - tailing, valley. The mercury from the anthropogenic human activity (like the Rudňany area) is in such environment superimposed to its geochemical background, while high concentration of mercury in the local scale may arise with its dangerous impacts on the environment.

\subsection{Earthworm bioassay and correlation coefficients}

The results of the toxicity tests are shown in Table 4. The largest mercury concentration differences were recorded in the samples Rudňany-tailing, valley $S$ (18.6mg/kg), Rudňany-tailing SED (14.2 mg/kg) and Rudňany-tailing, $S(7 \mathrm{mg} / \mathrm{kg})$, after 28 days earthworms exposure. It was found that earthworms (Dendrobaena veneta) in some cases caused decrease of mercury concentration in contaminated soils and sediments. The Pearson correlation coefficients for the mercury in the studied soil and sediment samples are summarized in Table 4. A significant positive correlation was found 
between highest concentrations of mercury Rudňanytailing SED $\mathrm{Hg}=188.5 \mathrm{mg} / \mathrm{kg} \quad(\mathrm{r}=0.87)$ with the highest mortality of Dendrobaena veneta after 28 days bioassay. From Table 4 it is evident that samples with the low concentrations of $\mathrm{Hg}$ did not influence significantly the mortality of earthworms. The correlation (positive and negative) found between the studied metals may show nearly similar levels and sources of contamination in the study area (Tang et al., 2013).

Table 2. Mercury concentration in different types of samples from Eastern Slovakia (total mercury concentration of the samples, mercury concentration of the samples after bioassay and accumulated in Dendrobaena veneta earthworm tissues during a 28-day bioassay (average \pm standard deviation)

\begin{tabular}{|c|c|c|c|}
\hline Area & $\begin{array}{l}\text { Hg Total concentration in } \\
\text { sample }(\mathrm{mg} / \mathrm{kg}) / \mathrm{d} . w .\end{array}$ & $\begin{array}{l}\text { Hg Concentration in sample } \\
\text { after bioassay }(\mathrm{mg} / \mathrm{kg}) / \mathrm{d} . w \text {. }\end{array}$ & $\begin{array}{l}\text { Hg Concentration in worms } \\
(\mathrm{mg} / \mathrm{kg}) / \mathrm{d} . w .\end{array}$ \\
\hline Hornád River SED & $8.7 \pm 2.2$ & $6.3 \pm 1.9$ & $0.17 \pm 0.02$ \\
\hline Hnilec River SED & $2.9 \pm 1.6$ & $2.1 \pm 1.2$ & $0.18 \pm 0.01$ \\
\hline Krompachy $1 \mathrm{KL}$ - PGV $\boldsymbol{S}$ & $1.9 \pm 2.1$ & $1.7 \pm 1.1$ & $0.09 \pm 0.002$ \\
\hline Krompachy 2KL - A $S$ & $1.7 \pm 1.6$ & $1.7 \pm 2.1$ & $0.12 \pm 0.01$ \\
\hline Krompachy 3KR - PGV $S$ & $4.8 \pm 3.3$ & $4.5 \pm 2.9$ & $0.29 \pm 0.09$ \\
\hline Krompachy 4KO - PGV $S$ & $20.6 \pm 7.4$ & $19.9 \pm 9.1$ & $0.54 \pm 0.05$ \\
\hline Krompachy - $a$ SED & $69.4 \pm 5.4$ & $69.9 \pm 4.1$ & $0.24 \pm 0.04$ \\
\hline Krompachy - $b$ SED & $93.4 \pm 8.2$ & $89.9 \pm 6.5$ & $0.98 \pm 0.06$ \\
\hline Rudňany - Matejovce $\boldsymbol{S}$ & $6.5 \pm 3.2$ & $5.5 \pm 2.9$ & $1.12 \pm 0.93$ \\
\hline Rudňany - tailing $\boldsymbol{S}$ & $82.5 \pm 6.1$ & $75.5 \pm 9.3$ & $11.3 \pm 5.0$ \\
\hline Rudňany- tailing, valley $S$ & $57.8 \pm 4.1$ & $39.2 \pm 7.3$ & $19.1 \pm 3.3$ \\
\hline Rudňany - tailing SED & $188.5 \pm 8.2$ & $174.3 \pm 9.3$ & $14.5 \pm 3.9$ \\
\hline Control $S$ & $0.5 \pm 0.2$ & $0.08 \pm 0.04$ & $0.420 \pm 0.003$ \\
\hline Control worms & & - & $0.036 \pm 0.002$ \\
\hline \multicolumn{4}{|c|}{ Norm used for comparison $(\mathrm{mg} / \mathrm{kg}$ ) Sediments } \\
\hline TV & - & - & 0.3 \\
\hline MPC & - & - & 10 \\
\hline IV & - & - & 10 \\
\hline \multicolumn{4}{|c|}{ Laws used for comparison $(\mathrm{mg} / \mathrm{kg}$ ) Soils } \\
\hline Limit value & - & - & 0.75 \\
\hline
\end{tabular}

S-Soils, SED-Sediments, PGV-permanent grass vegetation soils, A-agricultural soils, Norm No. 549/1998-2: TV-Target Value (Negligible Risk), MPC-Maximum Permissible Concentration (Max. Tolerable Risk), IV-Intervention Value (Serious Risk), Low No. 220/2004

Table 3. Mercury concentration in samples from the area of Rudňany (average \pm standard deviation)

Area

\begin{tabular}{clll}
\hline Rudňany - Matejovce & $0.064 \pm 0.02$ & $0.041 \pm 0.03$ & $0.047 \pm 0.02$ \\
\hline Rudňany - tailing & $0.124 \pm 0.03$ & $0.120 \pm 0.02$ & $0.125 \pm 0.04$ \\
\hline Rudňany - tailing, valley & $0.270 \pm 0.05$ & $0.031 \pm 0.03$ & $0.063 \pm 0.01$ \\
\hline
\end{tabular}




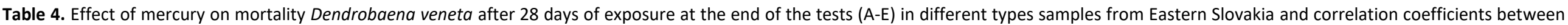
mercury and mortality earthworms ( $r$ - Pearson matrix correlation)

\begin{tabular}{|c|c|c|c|c|c|c|c|}
\hline \multirow[b]{2}{*}{ Area } & \multicolumn{7}{|c|}{ Repeats of test } \\
\hline & $\begin{array}{c}\text { Input of worms } \\
\text { No. }\end{array}$ & Mortality A (ANDE) & Mortality B (ANDE) & Mortality C (ANDE) & Mortality D (ANDE) & Mortality E (ANDE) & Pearson Matrix Correlation \\
\hline Hornád River SED & 10 & 3 & 1 & 2 & 3 & 2 & $r=0.3669$ \\
\hline Hnilec River SED & 10 & 1 & 2 & 2 & 1 & 1 & $r=0.3273$ \\
\hline Krompachy $1 \mathrm{KL} \mathbf{S}$ & 10 & 3 & 3 & 1 & 2 & 2 & $r=0.2182$ \\
\hline Krompachy $2 \mathrm{KL} S$ & 10 & 1 & 3 & 1 & 2 & 1 & $r=0.2004$ \\
\hline Krompachy 3KR S & 10 & 2 & 4 & 1 & 3 & 4 & $r=0.6054$ \\
\hline Krompachy 4KO S & 10 & 3 & 5 & 4 & 3 & 3 & $r=0.6394$ \\
\hline Krompachy a SED & 10 & 5 & 3 & 6 & 5 & 2 & $r=0.5418$ \\
\hline Krompachy b SED & 10 & 4 & 5 & 3 & 5 & 3 & $r=0.5403$ \\
\hline Rudňany Matejov. S & 10 & 2 & 2 & 3 & 2 & 3 & $r=0.7206$ \\
\hline Rudňany tailing $\mathbf{S}$ & 10 & 4 & 5 & 3 & 5 & 4 & $r=0.8501$ \\
\hline Rudňany tail.valley $\mathbf{S}$ & 10 & 3 & 5 & 2 & 4 & 2 & $r=0.8549$ \\
\hline Rudňany tailing SED & 10 & 6 & 4 & 6 & 3 & 6 & $r=0.8747$ \\
\hline Control S & 10 & 1 & 0 & 1 & 1 & 1 & $r=0.2500$ \\
\hline
\end{tabular}

(ANDE) - Absolute numbers of dead earthworms 


\section{Conclusions}

The aim of this study was the evaluation of mercury distribution and toxic effects in soils, sediments, plants from Eastern Slovakia, using earthworms. The high mercury concentrations were determined in the Rudnany tailing-SED (188.5 mg/kg), Krompachy a-SED (69.4 mg/ $\mathrm{kg}$ ), Krompachy b-SED $(93.4 \mathrm{mg} / \mathrm{kg})$, and the soils of the Rudňany-tailing-S ( $82.5 \mathrm{mg} / \mathrm{kg})$, Rudňany-tailing, valley-S $(57.8 \mathrm{mg} / \mathrm{kg}$ ) and Krompachy 4KO-S $(20.6 \mathrm{mg} / \mathrm{kg} \mathrm{Hg})$. It was found that earthworms (Dendrobaena veneta) in some cases caused decrease of mercury concentration in contaminated soils and sediments. A significant positive correlation was found between highest concentrations of mercury Rudňany-tailing SED $\mathrm{Hg}=188.5 \mathrm{mg} / \mathrm{kg} \quad(\mathrm{r}=0.87)$ with the highest mortality of Dendrobaena veneta after 28 days bioassay. The highest proportion of mercury from the soil accumulated to the birch leaves in the area Rudňany - tailing, valley. The high concentration of mercury in the study samples may lead to severe environmental and health impact. Therefore, it is important to understand the distribution of mercury in soils and sediments in relation to pollution control.

\section{Acknowledgements}

This work was supported by the Slovak Grant Agency for the VEGA projects No.2/0165/19 and 2/0055/17

\section{References}

Angelovičová L., Bobul'ská L. and Fazekašová D. (2015), Toxicity of heavy metals to soil biological and chemical properties in conditions of environmentally polluted area middle Spiš (Slovakia), Carpathian Journal of Earth and Environmental Sciences, 10/1, 193-201.

Aydin E.R.B., Ayeri T., Sisman Y. and Ardali Y. (2018), Evaluation of the anthropogenic impact in Suat Ugurlu Dam lake using multivariate statistical techniques, Global Nest Journal, 20/1, 161-168.

Babić S., Barišić J., Malev O., Klobučar G., Topić Popović N., Strunjak-Petrović I., Krasnci N. and Čož-Rakovec R. (2016), Sewage sludge toxicity assessment using earthworm Eisenia fetida: can biochemical and histopathological analysis provide fast and accurate insight?, Environmental science and pollution researcher, 23/12, 12150-12163.

Coelho C., Foret C., Bazin C., Leduc L., Hammada M., Inácio M. and Bedell J.P. (2018), Bioavailability and bioaccumulation of heavy metals of several soils and sediments (from industrialized urban areas) for Eisenia fetida, Science of the Total Environment, 635, 1317-1330.

Czerniawska-Kusza I. and Kusza G. (2011), The potential of the Phytotoxkit microbiotest for hazard evaluation of sediments in eutrophic freshwater ecosystems, Environmental Monitoring and Assessment, 179, 113-121.

Christofoletti C., Francisco A and Fontanetti C.S. (2012), Biosolid soil application: toxicity tests under laboratory conditions. Applied and Environmental Soil Science, doi: 10.1155/2012/518206.

Das K.S. and Chakrapani G.J. (2011), Assessment of trace metal toxicity in soils of Raniganj Coalfield, India, Environmental Monitoring and Assessment, 177, 63-67.
De Vaufleury A., Gimbert F. and Gomot L. (2013), Bioacumulation, bioamplification des polluants dans la faune terrestre, Un outil pour la biosurveillance des écosysrémes., Ed EDP Sciences, ADEME, Paris, France, p. 641.

Eijsackers H. (2010), Earthworms as colonizers: Primary colonization of contaminated land, and sediement and soil waste deposits, Science of the Total Environment, 408, 17591769.

Hinton J. and Veiga M. (2009), Using Earthworms to Assess $\mathrm{Hg}$ Distribution and Bioavailability in Gold Mining Soils, Soil and Sediment Contamination, 18, 512-524.

Kučerová G., Majzlan J., Lalinská-Voleková B., Radková A., Bačík P., Michňová J., Šotník P., Jurkovič L'., Klimko T., Steininger R and Göttlicher J. (2014), Mineralogy of neutral mine drainage in the tailings of siderite-Cu ores in eastern Slovakia, The Canadian Mineralogist, 1-20, DOI: 10.3749/canmin.1400020.

Law No.220/2004, Supp. 2, on the Protection and Use of Agricultural Land and on the Amendment to Act no. 245/2003 Coll. on Integrated Prevention and Control of Environmental Pollution, Slovak Republic.

Maity S., Poráčová J., Dey P., Vašková J., Vaško L., Sedlák V. and Mydlárová Blaščáková M. (2018) Antioxidant responses in the earthworm Aporrectodea caliginosa of eastern Slovakia: application of principal component analysis as a tool to identify metal contaminated areas, Environmental Monitoring and Assessment, 190:21, 1-16.

Mariyadas J., Amorim M.J.B., Jensen J. and Scott-Fordsmand J.J.(2018), Earthworm avoidance of silver nanomaterials over time. Environmental Pollution, 239, 751-756.

Nannoni F., Rossi S. and Protano G. (2014), Soil properties and metal accumulation by earthworms in the Siena urban area (Italy), Applied Soil Ecology, 77, 9-17.

Nogarol L.R. and Fontanetti C.S. (2010), Acute and subchronic exposure of diplopods to substrate containing sewage mud: tissular responses of the midgut, Micron, 41, 239-246.

Šestinová O., Findoráková L., Hančulák J. and Šestinová L. (2015), Study of metal mobility and phytotoxicity in bottom sediments that have influenced by former mining activities in Eastern Slovakia, Environmental Earth Sciences, 74/7, 60176025.

Šestinová O., Findoráková L., Dolinská S., Hančulák J., Špaldon T. and Fedorová E. (2015), Effect of environmental load on the toxicity of bottom sediments. Nova Biotechnologica et Chimica, 14/1, ISSN 1338-6905, 1-9.

Tang Q., Liu G.J., Zhang H. and Sun R.Y. (2013) Distribution of environmentally sensitive elements in residential soils near a coal-fired power plant: potential risks to ecology and children's health, Chemosphere, 93/10, 2473-2479, doi: 10.1016/j.chemosphere.2013.09.015.

Yin R., Feng X., Wang J., Li P., Liu J., Zhang Y., Chen J., Zheng L. and Hu T. (2013), Mercury speciation and mercury isotope fractionation during ore roasting process and their implication to source identification of downstream sediment in the Wanshan mercury mining area, SW China, Chemical Geology, 336, 72-79.

Zhang W.T., You M. and Hu Y.H. (2016), The distribution and accumulation characteristics of heavy metals in soil and plant from Huainan coalfield, China. Environmental Progress \& Sustainable Energy, 35/4, 1098-1104. doi:10.1002/ep.12336. 